\title{
Glucose Perturbation in Experimental Hyperviscosity
}

\author{
ROSEMARY D. LEAKE, ${ }^{(33)}$ GARY M. CHAN, SHEREEN ZAKAUDDIN, MICHAEL E. DODGE, \\ ROBERT H. FISER, DENNIS M. BIER, AND WILLIAM OH
}

Harbor/UCLA Medical Center, Department of Pediatrics, Torrance, California, USA

\section{Summary}

Hyperviscosity was produced in one member of each of 7 sets of twin newborn lambs by an exchange transfusion with $500 \mathrm{ml}$ maternal packed red blood cells. The remaining seven control twin lambs underwent an identical exchange with maternal whole blood. Postexchange hematocrits were $63 \pm 6$ and $29.0 \pm 3 \%$ (mean \pm S.E.), respectively $(P<0.01)$. Whole blood viscosity measured at $3 \mathrm{rpm}$ increased from $3.2 \pm 0.4$ centipoise (cps) to $14.4 \pm 6.1 \mathrm{cps}$ in the lambs made hyperviscous $(P<0.01)$ and remained unchanged in the control lambs $(2.2 \pm 0.2$ versus $2.8 \pm 0.3 \mathrm{cps})$.

A 2-hr steady state glucose infusion was performed on each lamb before and after the packed cell or whole blood exchange transfusion. Mean steady state plasma glucose concentrations were significantly decreased from pre-exchange steady state glucose infusion levels in the same lambs made hyperviscous $(P<$ 0.05 ), whereas steady state glucose levels increased from preexchange levels in the twin lambs exchanged with maternal whole blood. Mean plasma insulin and glucagon values for the hyperviscous and control lambs remained unchanged during the glucose infusion.

\section{Speculation}

The finding of an abnormality in glucose homeostasis in the absence of a hormonal or substrate disturbance in hyperviscous lambs suggests that there may be rapid glucose utilization from increased cerebral extraction of glucose and/or a reduction in endogenous glucose production caused by sluggish hepatic circulation.

There are many studies relating neonatal hypoglycemia to decreased glycogen stores $(22,25)$, hyperinsulinism $(1,8)$, increased metabolic demand $(5,7)$, and abnormalities in gluconeogenesis $(14,21)$. The hypoglycemia found commonly $(12,13,15$, 18 ) in the hyperviscous newborn is unexplained. Many hyperviscous infants are small for gestational age or infants of diabetic mothers, suggesting that their hypoglycemia might reflect limitations of gluconeogenesis, hyperinsulinism, or both.

In a previous study (16) utilizing intravenous (IV) glucose tolerance tests, we demonstrated increased glucose disappearance rates when hyperviscous infants (infants of diabetic mothers, small for gestational age infants, and infants whose hyperviscosity was of unknown etiology) were compared to control infants matched for conceptual age (16). In the hyperviscous infants, glucose disappearance rates decreased towards control values after partial exchange transfusion. Basal and stimulated plasma insulin, alanine, and growth hormone levels were similar to control values throughout the study period. Thus, there was suggestive evidence that the rapid rate constant for glucose outflow in the neonatal hyperviscosity syndrome was on the basis of mechanisms other than absolute hyperinsulinism or deficiency of a key gluconeogenic substrate (14) and was perhaps related to pathophysiologic considerations more fundamental to the underlying clinical diagnosis.
In the present study, we utilized the hyperviscous lamb model described by Fouron and Hebert (11) to investigate further the effects of hyperviscosity on glucose homeostasis and on certain of the key hormones affecting control of the blood glucose level.

\section{MATERIALS AND METHODS}

Fourteen full-term lambs were the subjects of the study. They were spontaneously delivered, full-term, healthy, 5- to 19-day-old Columbia-Suffolk twins. Lamb weights were 3 to $6 \mathrm{~kg}$; weights between lamb pairs were not significantly different. Carotid artery and internal jugular veins were catheterized under local anesthesia. A dilute heparin solution (4 units $/ \mathrm{ml}$ ) was used to maintain the patency of the catheters. The animals were allowed to nurse ad libitum from their respective mothers. Each was allowed at least one recovery day after surgery before study.

We first evaluated the rheologic characteristics of neonatal blood in 5 lambs. Six blood samples ( $2 \mathrm{ml}$ per sample) were withdrawn from each jugular vein catheter. Blood was placed in syringes previously rinsed with dilute heparin and air-dried. Blood samples were prepared with a range of hematocrits by the addition or subtraction of plasma from tubes containing the centrifuged whole blood.

The packed erythrocytes were resuspended by gentle agitation and viscometry of the fluid analyzed. The relationship between packed cell volume and viscosity was compared to published data from similar studies utilizing red blood cells from human newborns and adults $(18,23,26,29,30)$.

In a separate study, 14 lambs (seven twin sets) were separated from their mothers and fasted for 1 to $3 \mathrm{hr}$. All studies were conducted with the lambs lightly restrained and unanesthetized. Each animal received a 2-hr infusion of glucose at a rate of $6 \mathrm{mg} /$ $\mathrm{kg} \cdot \mathrm{min}$. through the jugular vein catheter by constant infusion pump (Holter Infusion Pump; Holter Co., Bridgeport, CT). The pump infusion speed was determined at appropriate intervals. Two-ml blood samples for plasma glucose were obtained via the carotid artery at $-30,0,30,60,90,105$, and $120 \mathrm{~min}$ and placed in iced tubes containing EDTA. Blood samples $(2 \mathrm{ml})$ were also obtained in an identical manner except for the addition of 1000 Kallikrein units of Traysylol (FBA Pharmaceutical, New York, NY) for hematocrit, plasma insulin, glucagon, lactate, and alanine at $0,30,60,90,105$, and $120 \mathrm{~min}$. Iced blood samples were promptly spun in a refrigerated centrifuge at $2000 \mathrm{rpm}$. The plasma was frozen at $-40^{\circ} \mathrm{C}$ until assay.

The lambs were returned to their mothers and allowed ad libitum feedings during the intervals between study. One to 4 days later, $1000 \mathrm{ml}$ of maternal ewe whole blood were removed via a jugular vein catheter into heparinized syringes. One of each pair of twins was chosen at random, separated from the ewe, and given an isovolemic exchange transfusion with $500 \mathrm{ml}$ heparinized maternal whole blood. The second of each twin pair was exchanged in an identical manner with maternal packed cells prepared from heparinized maternal whole blood by centrifuging for $20 \mathrm{~min}$ at $3000 \mathrm{rpm}$ and discarding the plasma. The glucose infusions outlined above were repeated in each twin pair $4 \pm 2.4 \mathrm{hr}$ (mean \pm 
S.E.) after the exchange transfusion, with identical blood sampling during the study period. There were no consistent bias between the control and hyperviscous lambs in the timing of the second glucose infusion. The animals remained fasting until the completion of the second glucose infusion.

Baseline and post-exchange viscosity measurements were determined on $1 \mathrm{ml}$ blood samples within $4 \mathrm{hr}$ of sampling time via a viscometer (Wells Brookfield Microviscometer model LVT/CIP, $0.8^{\circ}$ cone; Brookfield Engineering, Stoughton, MA), calibrated with repeated determinations using Bureau of Standard Oil $\mathrm{H}$ (Standard Calibration Oil H; Bureau of Standards, Washington D. C.) of known viscosity. Sample temperature was maintained at $37^{\circ} \mathrm{C}$ by means of water-jacketed sample cup attached to a constant temperature water bath (model $\mathrm{N}$ Constant Temperature Bath; Brookfield Engineering Laboratories, Inc., Stoughton, MA). Each sample was analyzed at shear rates of 212, 106, 42, and 11 $\mathrm{sec}^{-1}$ after at least 4 min of preliminary shearing. Viscometer scale readings were begun at $60 \mathrm{rpm}$ and then continued to each slower shear rate, allowing time for the viscometer needle to reach equilibrium after changing speeds.

This sequence of measurements was repeated twice and, the three values at each shear rate were averaged. Viscosity was

\section{VISCOSITY OF LAMBS BLOOD Shear Rate $=22.5 \mathrm{sec}^{-1}$}

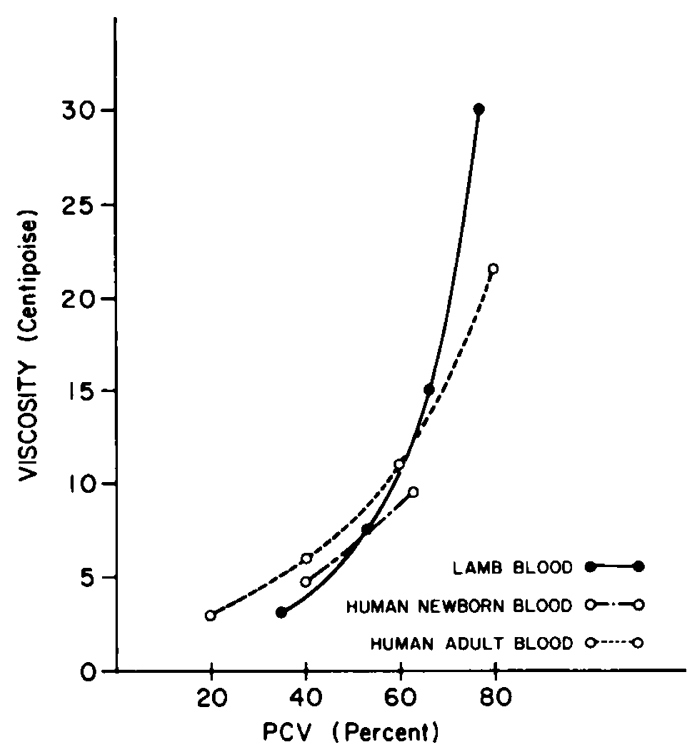

Fig. 1. The continuous curve ( $\rightarrow$ ) represents the mean values for the relationship between packed cell volume (\%) and viscosity (cps) in six samples from five lambs of whole blood reconstituted to various hematocrits. The lower, interrupted curve $(\mathrm{O}---\mathrm{O})$ is reproduced from the values reported by Gross et al. (12) of 102 healthy, appropriate for gestational age, term infants, and the upper, interrupted curve $(\mathrm{O}$ - - - O) represents data from 60 normal human adult, reported by Rand et al. (23). calculated as

$$
\frac{\text { shear stress }}{\text { shear rate }}=\text { dyne } / \mathrm{cm}^{2} \times 100=\text { centopoise }
$$

where

$$
\text { shear stress }=\frac{\% \text { torque }}{2 / 3 \text { spindle } \text { radius }^{3}}
$$

for non-Newtonian fluids $(4,31)$. In practice, viscosity is determined by multiplying the scale reading by a constant for each shear rate. Reproducibility of the scale reading is within $1.0 \%$ of the viscosity at full scale deflection at each rotational speed (19).

Hematocrits were measured in duplicate using the standard technique. Glucose was measured by the glucose oxidase method. Immunoreactive insulin was measured by a modification of the double antibody technique of Morgan and Lazarow (20). Glucagon was analyzed by double antibody radioimmunoassay (27). Lactate and alanine were determined microfluorometrically (17). For each sample period, comparisons were made between the control on (C) and hyperviscous lambs using the Student's $t$ test and between the pre- and post-exchange values on control and hyperviscous lambs using the paired $t$ test.

\section{RESULTS}

The rheologic studies on lamb whole blood reconstituted to various hematocrits are shown in Figure 1. The relationship between packed cell volume and viscosity of lamb blood is comparable to that of human newborn and adult blood. There is a steep increase in viscosity at a hematocrit $>60 \%$ in both lamb and human blood.

The effect of exchange transfusion on mean packed cell volume and blood viscosity is shown in Table 1 . Viscometry at $3 \mathrm{rpm}(225$ $\mathrm{sec}^{-1}$ shear rate) is presented because this rate correlates with arteriolar flow, the area of the vascular circulation presenting the major part of total flow resistance. Hematocrit postexchange was $29.0 \pm 3 \%$ for the lambs exchanged with maternal whole blood and $63 \pm 6 \%$ for the lambs with maternal packed cell exchange $(P<0.01)$. Mean viscosity was $2.8 \pm 0.3$ centipoise (cps) for the lambs with maternal exchange, and $14.4 \pm 6.1 \mathrm{cps}$ for the lambs with maternal exchange $(P<0.01)$. Thus the hyperviscous lamb model was confirmed.

The sequential response of plasma glucose during the constant infusion of glucose at $6 \mathrm{mg} / \mathrm{kg} \cdot \min$ for twin lambs studied before and after exchange transfusion with maternal whole blood (control group) is shown in Fig 2. Baseline glucose values before glucose infusion before and after exchange were not different.

During the glucose infusion plasma glucose concentration increased by $19 \pm 4 \mathrm{mg} / \mathrm{dl}$ above fasting basal values to a peak of $108 \pm 2 \mathrm{mg} / \mathrm{dl}$ in the lambs before exchange and increased more rapidly to a peak of $127 \pm 13 \mathrm{mg} / \mathrm{dl}(37 \pm 8 \mathrm{mg} \%$ above baseline) in the same lambs after maternal whole blood exchange. By 60 to $90 \mathrm{~min}$, however, there were no significant differences in the serial glucose values for the pre- or post-exchange groups.

The sequential changes in plasma glucose before and after the exchange transfusion with maternal packed cells (hyperviscous

Table 1. Packed cell volume and whole blood viscosity of lambs exchange transfused with whole blood (control) or packed red blood cells (hyperviscous) ${ }^{1}$

\begin{tabular}{lccccc}
\hline & \multicolumn{2}{c}{ Pre-exchange } & & \multicolumn{2}{c}{ Post-exchange } \\
\cline { 2 - 3 } \cline { 5 - 6 } & Packed cell volume (\%) & Viscosity ${ }^{2}(\mathrm{cps})$ & & Packed cell volume (\%) & Viscosity (cps) \\
\hline Control & $20 \pm 1^{3}$ & $2.2 \pm 0.2$ & & $29 \pm 3$ & $2.8 \pm 0.3$ \\
Hyperviscous & $30 \pm 12$ & $3.1 \pm 0.4$ & & $63 \pm 6^{4}$ & $14.4 \pm 6.1^{4}$ \\
\hline
\end{tabular}

${ }_{1}^{1}$ The effect of exchange transfusion with maternal whole blood (control group) and maternal packed red cells (hyperviscous group) on newborn lamb packed cell volume and viscosity.

${ }^{2}$ Measured at $3 \mathrm{rpm}$.

${ }^{3}$ Mean \pm S.E.

${ }^{4} P<0.01$. 


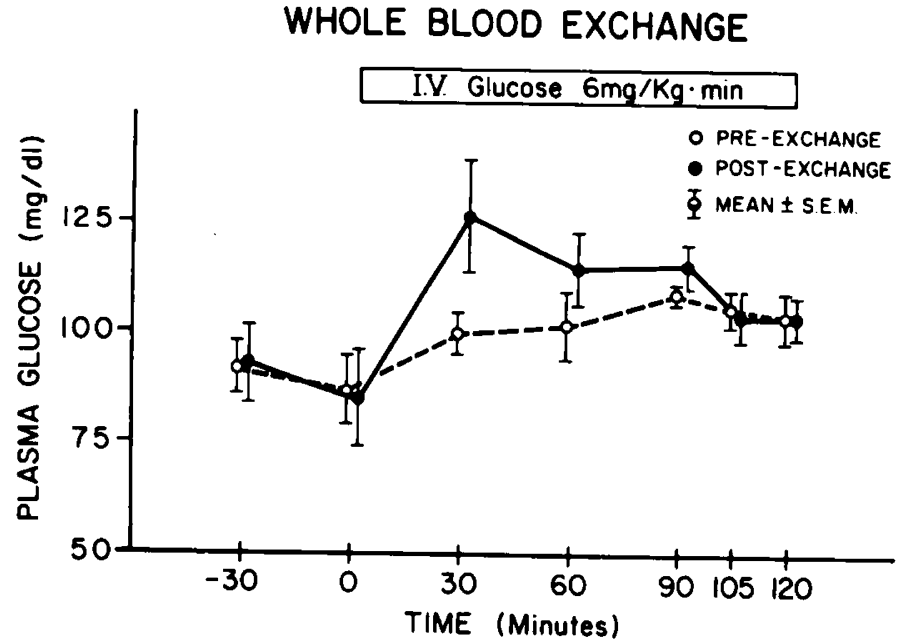

Fig. 2. Sequential response of plasma glucose $(\mathrm{mg} / \mathrm{dl})$ after constant infusion of glucose, $6 \mathrm{mg} / \mathrm{kg} \cdot \min$., measured before $(O)$ and after $(\theta)$ exchange with $500 \mathrm{ml}$ maternal whole blood. Mean \pm S.E. of seven twin lambs.

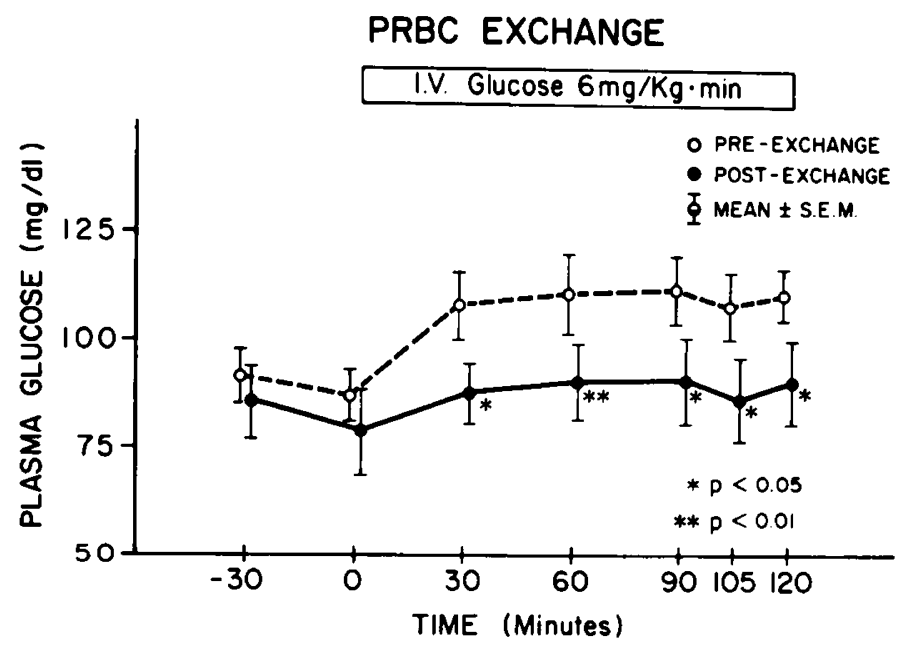

Fig. 3. Sequential response of plasma glucose $(\mathrm{mg} / \mathrm{dl})$ after constant infusion of glucose $6 \mathrm{mg} / \mathrm{kg} \cdot \min$ measured before $(O)$ and after $(O)$ exchange with $500 \mathrm{ml}$ maternal packed cells. Mean \pm S.E. of seven twin lambs. $\left({ }^{*}, P<0.05 ;{ }^{* *}, P<0.01\right.$ by paired $t$ test pre- versus post-exchange values). group) are shown in Fig. 3. Plasma glucose concentration increased by $18 \pm 3 \mathrm{mg} / \mathrm{dl}$ above fasting basal levels during the constant glucose infusion before exchange transfusion. These glucose values were not significantly different from those of the control twin lambs pre- or post-exchange with maternal whole blood (Fig. 2). However, after exchange transfusion with maternal packed cells, and during 30 to $120 \mathrm{~min}$ of constant glucose infusion, the hyperviscous lambs evidenced a slight, but not statistically significant, increase in plasma glucose concentration above baseline. These values were significantly less $(P<0.05)$ than pre-exchange values and also significantly less $(P<0.05)$ than plasma glucose values attained in the control lambs both before and after the exchange transfusion with whole blood.

In an attempt to explain the observed lower plasma glucose levels accompanying the hyperviscous state, we measured plasma insulin and glucagon in both groups, as well as alanine and lactate in two animals each in the control and hyperviscous groups.

As shown in Table 2, serial concentrations of plasma insulin and glucagon were not significantly different at any time point during the studies for control and hyperviscous lambs. All the variables were within the range previously reported by us $(6,9$, $10)$ and by other investigators (2). There were no differences in pre- and post-exchange values for either group.

Plasma lactate and alanine were measured at the various sampling times in two lambs before and after whole blood exchange and in two lambs before and after packed cell exchange. Plasma lactate concentrations varied from 1132 to $1420 \mathrm{~mm}$ in the control lambs and from 999 to $1620 \mathrm{~mm}$ in the hyperviscous lambs. Plasma alanine levels varied from 143 to $204 \mathrm{~mm}$ in the control lambs and 172 to $213 \mathrm{~mm}$ in the hyperviscous lambs. There were no significant differences at any time point.

\section{DISCUSSION}

Fouron and Hebert (11) performed exchange transfusion with maternal packed cells in twin lambs to examine the cardiovascular effects of high hematocrits. Although it is known that rheologic properties of the red cells are similar in human blood and that of the dog, hamster, rhesus monkey, and baboon (19), there are no studies of the rheologic characteristics of newborn lambs red cells. Our current data include the confirmation of the similarity in the rheologic characteristics of the lamb and human erythrocyte. The data also indicate that the hyperviscous lamb model may be useful for metabolic studies.

The data from our preliminary study measuring lambs' red blood cells reconstituted to various hematocrits demonstrated a sharp rise in viscosity when a hematocrit of 60 or greater was achieved. These viscosity-packed cell relationships were compa-

Table 2. Sequential response of plasma insulin and glucagon to a constant infusion of $6 \mathrm{mg} / \mathrm{kg} \cdot \mathrm{min}$ glucose in control and hyperviscous lambs ${ }^{1}$

\begin{tabular}{|c|c|c|c|c|c|c|c|}
\hline & & Baseline $^{2}$ & $30^{\prime \prime}$ & $60^{\prime \prime}$ & $90^{\prime \prime}$ & $105^{\prime \prime}$ & $120^{\prime \prime}$ \\
\hline \multicolumn{8}{|l|}{ Plasma } \\
\hline \multirow[t]{2}{*}{ Insulin $^{3}(\mu \mathrm{U} / \mathrm{ml})$} & $\begin{array}{l}\text { Pre-exchange } \\
\text { Control post-exchange }\end{array}$ & $\begin{array}{l}21 \pm 2^{4} \\
22 \pm 2\end{array}$ & $\begin{array}{l}35 \pm 3 \\
38 \pm 7\end{array}$ & $\begin{array}{l}28 \pm 3 \\
33 \pm 3\end{array}$ & $\begin{array}{l}26 \pm 2 \\
26 \pm 2\end{array}$ & $\begin{array}{l}23 \pm 1 \\
23 \pm 2\end{array}$ & $\begin{array}{r}23.5 \pm 5 \\
22 \pm 1\end{array}$ \\
\hline & $\begin{array}{l}\text { Pre-exchange } \\
\text { Hyperviscous post-exchange }\end{array}$ & $\begin{array}{l}23 \pm 4 \\
22 \pm 2\end{array}$ & $\begin{array}{r}32.2 \pm 7 \\
29 \pm 4\end{array}$ & $\begin{array}{r}33.5 \pm 4 \\
32 \pm 4\end{array}$ & $\begin{array}{l}33 \pm 5 \\
37 \pm 7\end{array}$ & $\begin{array}{l}28 \pm 5 \\
24 \pm 2\end{array}$ & $\begin{array}{l}29 \pm 4 \\
29 \pm 3\end{array}$ \\
\hline \multirow[t]{2}{*}{ Glucagon $^{3}(\mathrm{pg} / \mathrm{ml})$} & $\begin{array}{l}\text { Pre-exchange } \\
\text { Control post-exchange }\end{array}$ & $\begin{array}{l}260 \pm 14 \\
258 \pm 11\end{array}$ & $\begin{array}{l}270 \pm 16 \\
263 \pm 21\end{array}$ & $\begin{array}{l}270 \pm 19 \\
270 \pm 21\end{array}$ & $\begin{array}{l}277 \pm 23 \\
275 \pm 22\end{array}$ & $\begin{array}{l}263 \pm 14 \\
252 \pm 20\end{array}$ & $\begin{array}{l}259 \pm 17 \\
260 \pm 20\end{array}$ \\
\hline & $\begin{array}{l}\text { Pre-exchange } \\
\text { Hyperviscous post-exchange }\end{array}$ & $\begin{array}{l}247 \pm 5 \\
238 \pm 12\end{array}$ & $\begin{array}{l}249 \pm 7 \\
242 \pm 12\end{array}$ & $\begin{array}{l}255 \pm 9 \\
240 \pm 12\end{array}$ & $\begin{array}{l}259 \pm 7 \\
240 \pm 15\end{array}$ & $\begin{array}{l}255 \pm 8 \\
240 \pm 12\end{array}$ & $\begin{array}{l}231 \pm 10 \\
218 \pm 2\end{array}$ \\
\hline
\end{tabular}

${ }^{1}$ Not significant at any time point.

2 Mean of -30 and 0 values.

${ }^{3} N=7$.

${ }^{4}$ Mean \pm S.E. 
rable to those found in the human newborn and adult $(18,23,26$, 29,30 ).

Newborn lambs lack antibodies against maternal ewe cells so that after a partial exchange transfusion of $500 \mathrm{cc}$ maternal packed cells, it was possible to produce a normovolemic hyperviscous state in the lamb.

Using the model, we found that steady-state plasma glucose concentrations during intravenous (IV) glucose infusion of $6 \mathrm{mg} /$ $\mathrm{kg} / \mathrm{min}$ were significantly lower in the hyperviscous lambs when compared to the same lambs before exchange or to the lamb twin before or after exchange transfusion with maternal whole blood.

We have previously shown that insulin and glucagon play a significant role in modulating glucose homeostasis in the newborn period with glucagon playing the dominant role during short-term fasting (28). In the present study, there were no differences, however, between serial measurements of plasma insulin and glucagon in the control and hyperviscous lambs. In addition, growth hormone values were similar pre- and post-hyperviscosity in our human newborn studies (16). Thus, the key carbohydrate regulatory hormones are normal in the hyperviscous state.

Because lactate is the principal metabolic product of glycolysis in the red cell and because lactate and alanine are major gluconeogenic precursors, we also measured plasma levels of these substrates in two animals from each study group. As for the hormone values, the alanine and lactate levels in the hyperviscous animals were the same as those of the control twins in the limited number of animals studied. What then is the origin of the hypoglycemia observed in the hyperviscous state? The present study does not answer this question directly but eliminates certain possibilities and presents several others. The exchange transfusion might produce a catecholamine mediated effect, but this should decrease glucose utilization and glucose clearance, an effect opposite the one suggested by our results, particularly in the hyperviscous animals. We had previously reported that there is a highly significant correlation between glucose production and estimated brain weight throughout the pediatric age range and that the child's brain is responsible for the bulk of glucose utilization (3) as is the situation in the adult.

Cerebral circulation is known to be slowed in the hyperviscous state (24), and it is possible that this allows increased glucose extraction in cerebral tissues. Additionally, the presence of tissue hypoxia in the liver because of sluggish hepatic circulation may depress endogenous glucose production. The combination of increased glucose disposal in the cerebral circulation and decreased hepatic glucose output may result in the consistently lower plasma glucose concentration observed during the constant glucose infusion.

\section{REFERENCES AND NOTES}

1. Baird, J. D., and Farquhar, J. W.: Insulin-secreting capacity in newborn infants of normal and diabetic women. Lancet, $1: 71$ (1962).

2. Bassett, J. M.: Plasma glucagon concentrations in sheep: their regulation and relation to concentrations of insulin and growth hormone. Aust. J. Biol. Sci., 25: 1277 (1972)

3. Bier, D. M., Leake, R. D., Haymond, M. W., Arnold, K. J., Gruenke, L. D., Sperling. M. A., and Kipnis, D. M. Measurement of "true" glucose production rates in infancy and childhood with 6,6-dideuteroglucose. Diabetes, 26: 1016 (1977).

4. Bingham, E. C., and Roepke, R. R.: The fluidity of whole blood at $37^{\circ} \mathrm{C}$. J. Gen. Physiol., 28: 131 (1944)

5. Cake, M. H., Yeung, D., and Oliver, I. T.: The control of postnatal hypoglycemia. Biol Neonate, 18: 183 (1971).
6. Cowett, R. M., Susa, J. B., Oh, W., and Schwartz, R.: Endogenous glucose production during constant glucose infusion in the newborn lamb. Pediatr. Res., 10: 407 (1976)

7. Dawkins, M. J. R.: Hypoglycemia in childhood. Proc. R. Soc. Med., 57: 1063 (1964).

8. Farquhar, J. W.: Maternal hyperglycemia and foetal hyperinsulinism in diabetic pregnancy. Postgrad. Med. J., 38: 612 (1962)

9. Fiser, R. H., Phelps, D. L., Williams, P. R., Sperling, M. A., Fisher, D. A., and Oh, W.: Insulin-glucagon substrate interrelationships in the neonatal sheep. Am. J. Obstet. Gynecol., 120: 944 (1974).

10. Fiser, R. H., Phelps, D. L., Williams, P. R., Sperling, M. A., Oh, W., and Fisher, D. A.: Alanine stimulation of the pancreatic alpha and beta cell in the neonatal lamb. Biol Neonate, 25: 171 (1974)

11. Fouron, J. C., and Hebert, F.: The circulatory effects of hematocrit variations in normovolemic newborn lambs. J. Pediatr., 82: 995 (1973)

12. Gross, G. P., Hathaway, W. E., and McGaughey, H. R.: Hyperviscosity in the neonate. J. Pediatr., 82: 1004 (1973).

13. Haworth. J. C., Dilling, L., and Younoszai, M. K.: Relation of blood glucose to hematocrit, birthweight and other body measurements in normal and growth retarded newborn infants. Lancet, 2: 901 (1967).

14. Haymond, M. W., Karl, I. E., and Pagliara, A. S.: Increased gluconeogenic substrates in the small-for-gestational-age infant. N. Engl. J. Med., 291: 322 (1974).

15. Humbert, J. R., Abelson, H., Hathaway, E. E., and Battaglia, F. C.: Polycythemia in small for gestational age infants. J. Pediatr., 75: 812 (1969).

16. Leake, R. D., Chan, G. A., Zakauddin, S., Dodge, M. E., Fiser, R. H., and Oh, W.: Glucose utilization in hyperviscosity. Pediatr. Res., 10: 412 (1976)

17. Lowry, O. H., and Passonneau, J. V.: A flexible system of enzymatic analysis (Academic Press, Inc., New York, 1972).

18. Mackintosh, T. F., and Walker, C. H.: Blood viscosity in the newborn. Arch. Dis. Child., 48: 547 (1973).

19. Merrill, E. W.: Rheology of blood. Physiol. Rev., 49: 863 (1969)

20. Morgan, C. R., and Lazarow, A.: Immunoassay of insulin using a two antibody system. Proc. Soc. Exp. Biol. Med., 110: 29 (1962).

21. Nitzan, M., and Groffman, H.: Hepatic gluconeogenesis and lipogenesis in the experimental intrauterine growth retardation in the rat. Am. J. Obstet. Gynecol., 109: 623 (1971).

22. Oh, W., D'Amodio, M. D., Yal, L. L., and Hohenauer, L.: Carbohydrate metabolism in experimental intrauterine growth retardation in rats. Am. J. Obstet. Gynecol., 108: 415 (1970).

23. Rand, P. W., Lacombe, E., Hunt, H. E., and Austin, W. H.: Viscosity of norma human blood under normothermic and hypothermic conditions. J. Appl. Physiol., 19: 117 (1964)

24. Rosenblum, W. I.: Effects of blood pressure and blood viscosity on fluorescein transit time in the cerebral microcirculation in the mouse. Circ. Res., 27: 825 (1970).

25. Shelley, H. J., and Neligan, G. S.: Neonatal hypoglycemia. Br. Med. Bull., 22: 34 (1966)

26. Sommer, A., and Kontras, S. B.: Studies of blood viscosity in the normal newborn Biol. Neonat., 17: 441 (1971).

27. Sperling, M. A., DeLamater, P., Fiser, R. H., Jr., Fisher, D. A., and Kazenelson, M.: Development and application of a radioimmunoassay for glucagon. $C$ lin. Chem., 20: 566 (1975).

28. Sperling, M. A., Grajwer, L., Leake, R. D., and Fisher, D. A.: Effects of somatostatin (SRIF) infusion on glucose homeostasis in the newborn lambs. Evidence for a significant role of glucagon. Pediatr. Res., 11: 962 (1977).

29. Virgilio, R. W., Long, D. M., Mundth, E. D., and McClenathan, J. E.: The effect of temperature and hematocrit on the viscosity of blood. Surgery, 55: 825 (1964)

30. Wells, R. E.: Rheology of blood in the microcirculation. N. Engl. J. Med., 270: 832 (1964).

31. Wells, R. E., Jr., Denton, R., and Merrill, E. W.: Measurement of viscosity of biologic fluids by cone plate viscometer. J. Lab. Clin. Med., 57: 646 (1961).

32. This work was presented in part at The Society for Pediatrics Research, April, 1976, St. Louis, MO.

33. Requests for reprints should be addressed to: Rosemary Leake, M.D., Departmen of Pediatrics, Harbor/UCLA Medical Center, 1000 Carson Street, Torrance. CA 90509 (USA).

34. This research was supported in part by Grant HD10667, the National Institute of Child Health and Human Development, by General Research Support Grant 2355, National Institutes of Health, and a grant from the National Foundation, March of Dimes.

35. Received for publication October 2, 1979.

36. Accepted for publication March 19, 1980. 